\title{
UNDERSTANDING CIVIL LAW IN THE CONTEXT OF CONTEMPORARY ISLAM IN INDONESIA
}

\author{
Karman \\ Institut Agama Islam Sultan Muhammad Syafiuddin Sambas, Indonesia \\ h.karman.msi.mh@gmail.com
}

Received: 22-09-2021

Revised: 1-11-2021

Accepted: 22-11-2021

\begin{abstract}
This article aims to better understand civil law in the context of modern Islam in Indonesia by reviewing several publications that address civil law in the context of Islam from an Islamic standpoint. This article was conducted using a qualitative method. Then, utilizing coding and assessment methods, we examined the data to understand the primary issue fully. Because the research was performed during a pandemic, government restrictions limited public mobility; we relied on secondary data. Finding civil law in an Islamic context, marriage law in an Islamic context that emphasizes an Islamic view following the state's view, how is the evidence for studying civil law in an Islamic context; including the primary law of the individual section, civil family law, and inheritance law in an Islamic context are among the highlights of our findings. We can conclude that Islamic civil law encompasses Munakahat (all aspects of marriage, divorce, and their legal consequences); Wiratsat (all aspects of heirs, heirs, inheritance, and inheritance distribution); and Mu'amalah (all aspects of material things and rights to objects, as well as human relations).
\end{abstract}

Keywords: Civil law, contemporary Islam, understanding law, and literature review.

\begin{abstract}
Abstrak
Artikel ini bertujuan untuk lebih memahami hukum perdata dalam konteks Islam modern di Indonesia dengan meninjau beberapa publikasi yang membahas hukum perdata dalam konteks Islam dari sudut pandang Islam. Artikel ini dilakukan dengan menggunakan metode kualitatif. Kemudian, dengan menggunakan metode pengkodean dan penilaian, kami memeriksa data untuk memahami masalah utama sepenuhnya. Karena penelitian dilakukan selama pandemi, pembatasan pemerintah membatasi mobilitas publik; kami mengandalkan data sekunder. Menemukan hukum perdata dalam konteks Islam, hukum perkawinan dalam konteks Islam yang menekankan pandangan Islam mengikuti pandangan negara, bagaimana bukti untuk mempelajari hukum perdata dalam konteks Islam; termasuk hukum utama dari bagian individu, hukum keluarga sipil, dan hukum waris dalam konteks Islam adalah salah satu highlights dari temuan kami. Dapat kami simpulkan bahwa hukum perdata Islam meliputi munakahat (seluruh aspek perkawinan, perceraian, dan akibat hukumnya); Wiratsat (segala aspek ahli waris, ahli waris, pewarisan, dan pembagian harta warisan); dan Mu'amalah (segala aspek materi dan hak atas benda, serta hubungan antarmanusia).
\end{abstract}

Kata Kunci : Pemahaman Hukum perdata, Islam kontemporer, pemaham hukum, dan telaah literatur. 


\section{INTRODUCTION}

The historical background of common law in Indonesia is identified with the historical background of European common law. In 1804, a common-law called the Code Civil de Francais was compiled. ${ }^{1}$ From 1809-1811, France colonized the Netherlands and performed Wetboek Napoleon Ingeriht Voor het Koninkrijk Hollad. Uniquely, in 1814 the Dutch systematized this action into the Civil Code. On July 6, 1830, the draft law was completed, effectively creating the Burgerlijik Wetboe (Book of the Dutch Civil Code) and the Wetboek van Koophandle (Book of Commercial Law). ${ }^{2}$ When the Dutch colonized Indonesia, they applied both laws. In 1948, Indonesia officially established the two codes based on the concordance rules (political guidelines). So, with a civil law background, Indonesia, once a Dutch colonial country, still uses civil law. However, along with Islamic data, slowly Islamic law also colored the time of Indonesia's independence until the current independence era. ${ }^{3}$

Common civil law is a guideline that directs the relationship between legal subjects in the public's eyes. Strictly speaking, common civil law can be interpreted as something different from criminal law. ${ }^{4}$ The general laws are separated into four, to be specific. Laws about oneself, guidelines regarding having rights and acting alone, family law, guardianship, and accuracy are essential. Inheritance law regulates matters concerning a person's property or wealth if he bites the dust, and it also regulates the outcome of family relations on one's inheritance. ${ }^{5}$

In contrast to criminal law, civil law itself is private, which focuses on regulating the relationship between individuals; in other words, it focuses on individual interests. ${ }^{6}$ The material general law is the legal principle that regulates freedom and social commitment.

\footnotetext{
${ }^{1}$ Erick Christian Fabrian Siagian dkk., "SEJARAH SISTEM HUKUM EROPA KONTINENTAL (CIVIL LAW) DAN IMPLEMENTASINYA DI INDONESIA,” JURNAL LEX SPECIALIS 2, no. 1 (2021).

${ }^{2}$ Sri Hajati, Ellyne Dwi Poespasari, dan Oemar Moechthar, Buku Ajar Pengantar Hukum Indonesia (Airlangga University Press, 2019).

${ }^{3}$ Bella Aristantia Harto, "Tinjauan Sosiologi Hukum Islam Terhadap Pergeseran Peran dan Fugsi SuamiIsteri dalam Keluarga TKW di Desa Pucanganom Kecamatan Kebonsari Kabupaten Madiun” (PhD Thesis, IAIN Ponorogo, 2021). Aslan, "Pergeseran Nilai Di Masyarakat Perbatasan (Studi tentang Pendidikan dan Perubahan Sosial di Desa Temajuk Kalimantan Barat)," Disertasi dipublikasikan (Pasca Sarjana, 17 Januari 2019), https://idr.uin-antasari.ac.id/10997/.

${ }^{4}$ Antonin Scalia, Common-law courts in a civil-law system: the role of united states federal courts in interpreting the constitution and laws (Princeton University Press, 2018).

${ }^{5}$ S. H. PNH Simanjuntak, Hukum Perdata Indonesia (Kencana, 2017). Djaja S. Meliala, "Hukum Waris Menurut Kitab Undang-Undang Hukum Perdata” (Nuansa Aulia, 2018).

${ }^{6}$ Delila Kania, "Pembelajaran Konsep Hukum Perdata untuk Meningkatkan Kebermaknaan Pendidikan Kewarganegaraan,” Jurnal Wawasan Yuridika 31, no. 2 (2016): 154-76.
} 
When viewed in terms of capacity, common law consists of two kinds - limiting the law and material common law. ${ }^{7}$

Common or civil law is the overall arrangement of decisions that focuses on one individual's relationship. ${ }^{8}$ Rahmatullah, ${ }^{9}$ characterizes common law as a law that directs the individual interests of the population and other people. This law is centered on the interests of the individual and provides draconian authorizations for proposed offenses as specified in the Civil Code. Common law in Indonesia has a recurring theme with common law in mainland Europe. In 1814. When the Dutch colonized Indonesia, the Netherlands also applied these two laws in its colonized countries, including Indonesia. ${ }^{10}$ Then in 1948, based on the standard of concordance (political rules), Indonesia authoritatively enacted the two laws. As an indication of progress, the Dutch Civil Code was drawn up, and the Wetboek van Koophandle, the Commercial Code. ${ }^{11}$

Likewise, all the basic civil laws in Indonesia attached have summarized examples of legal articles per day that apply in Indonesia. ${ }^{12}$ There are two springs of everyday law: common law or habits that are specifically structured and unwritten. The following are examples from well-known legal sources, which rely on concordance standards. There are two familiar law sources, namely common law or custom, specifically structured and unwritten, and various familiar law sources. In contrast to criminal law, common law directs the relationship between people who plan to protect the public interest. Learning by using the model is more accessible for someone to capture the substance of the example. ${ }^{13}$ Common law regulates relations between people, in contrast to criminal law, which guarantees the public interest. There are two sources of general law, mainly structured and unwritten law or custom, and many other sources of structured law. ${ }^{14}$ The specifications for halal goods from the Dutch East Indies that apply in Indonesia depend on concordance standards. The

\footnotetext{
${ }^{7}$ Gerald J. Postema, A Treatise of Legal Philosophy and General Jurisprudence: Volume 11: Legal Philosophy in the Twentieth Century: The Common Law World, vol. 11 (Springer Science \& Business Media, 2011).

${ }^{8}$ Tengku Erwinsyahbana, "Sistem hukum perkawinan pada Negara hukum berdasarkan pancasila," jurnal ilmu bukum 3, no. 1 (2012).

${ }^{9}$ Indra Rahmatullah, "Meneguhkan Kembali Indonesia Sebagai Negara Hukum Pancasila," ADALAH 4, no. 2 (2020).

${ }^{10}$ Idik Saeful Bahri, Risalah Mabasiswa Hukum (Rasibook, 2017).

${ }^{11}$ Marhaeni Ria Siombo dan Henny Wiludjeng, Hukum Adat Dalam Perkembangannya (Penerbit Universitas katolik Indonesia Atma Jaya, 2020).

${ }^{12}$ Tariq Ramadan, Western Muslims and the future of Islam (Oxford University Press, 2003).

${ }^{13}$ S. H. I. Jonaedi Efendi, S. H. Johnny Ibrahim, dan MM SE, Metode Penelitian Hukum: Normatif dan Empiris (Prenada Media, 2018).

${ }^{14}$ Taufiq Wibowo, "Studi perbandingan hukum pengaturan kewenangan kejaksaan dalam penuntutan perkara pidana menurut kitab undang-undang hukum acara pidana (KUHAP) dan menurut hukum acara pidana Jepang (Japan Criminal Procedure Code)," 2010.
} 
presence of this law prevents the ratification of the power of Book II of the Criminal Code, which is identical to land rights other than contracts. Learning by using the model makes it easier for someone to capture the contents of the illustration, so the following has summarized examples of everyday legal articles that apply in Indonesia. ${ }^{15}$

Toward the end, there are likewise instances of the use of common law. For instance, somebody named Tono was sued by a lady, specifically Paulina, to pay remuneration for acquiring a dress and sack just as minor misfortunes since he had broken his guarantee. In this illustration, we have examined the significance of common law in Indonesia and then concentrated on its items. According to a legal perspective, Paulina could not document a claim in court since she did not meet the prerequisites of the claim. The question that happened did not abuse the privileges of the offended party, and there are no thoughtful law arrangements that are disregarded, overlooked, and not satisfied.

\section{METHOD}

This method section describes the procedures and approaches to data collection and analysis processes so that this study can answer the research questions. The problem of this study is to understand civil law in the context of contemporary Islam in Indonesia through a review of many publications that discuss civil law in the context of Islam from an Islamic point of view. We used a qualitative approach to conduct this research. ${ }^{16}$ Then we analyzed the data using coding and evaluation techniques to understand the main problem completely. We used secondary data because the study was conducted during a pandemic where government policies restricted public movement. The essence of our findings includes civil law in an Islamic perspective, marriage law in an Islamic context which emphasizes an Islamic view following the state's view, how is the evidence for studying civil law in an Islamic context; including the primary law of the individual section, civil family law, inheritance law in the Islamic context. ${ }^{17}$

${ }^{15}$ Nugraha Pranadita, Pemodelan Implementasi Hukum: Peranan Manajemen Strategis dalam Implementasi Hukum (Deepublish, 2018).

${ }^{16}$ Katerina Linos dan Melissa Carlson, "Qualitative methods for law review writing," U. Chi. L. Rev. 84 (2017): 213

${ }^{17}$ Joseph M. McKenna, Kathy Martinez-Prather, dan Scott W. Bowman, "The roles of school-based law enforcement officers and how these roles are established: A qualitative study," Criminal Justice Policy Review 27, no. 4 (2016): 420-43. 


\section{DISCUSSION}

\section{Civil law according to Islam.}

In Indonesia, there are two kinds of law, namely private law, and public law. Private law concerns legal outcomes cantered on individual interests, while public law affects a more comprehensive local area. ${ }^{18}$ General Islamic law is a positive law that applies in Indonesia, which is sourced from Islamic law (which is Islamic teachings sourced from the Qur'an). Improving Islamic law in Indonesia is new because not all Islamic countries have it. ${ }^{19}$ In Saudi Arabia, for example, there is not a single authoritative guide item used as an aid in state existence. ${ }^{20}$ What is remembered for general Islamic law can include family law, financial law, political law, procedural law, and so on, which are essential to the abundance of legal information in Indonesia and are trained in every legal workforce at all universities. ${ }^{21}$

Islamic law born in Indonesia is described as Islamic law that has existed for quite a long time among individuals, as stated by specific experts. ${ }^{22}$ In the most opportune moments of the development of Islam in Indonesia, the emphasis was on Sufism, and then Islamic law was associated with Islam as a religion. Muslims in the district were then followed by establishing the main Islamic territory around the 13th century known as Samudera Pasai, which is located in the sky of Java. The Western (European) common law framework, as regulated in the Burgeliik Wetboek, depends on the arrangement of articles. ${ }^{23}$ The Dutch need to organize a legal life in Indonesia, with the stages of a critical approach, namely: $\backslash \mathrm{r}$ a. Acceptance Theory (Snouck Hurgronje) (1857-1936) compiled by C. Van \r Vollenhoven and Ter Harr Bzn (1845-1927). ${ }^{24}$ This hypothesis states that Islamic law has legal force if it is recognized by common law. The consequences of this hypothesis bring about a turn of events and legal developments in which Islam has become slower than the different organizations in the archipelago. ${ }^{25}$

\footnotetext{
${ }^{18}$ Kerstin Steiner, "Islam, Law, and Human Rights of Women in Malaysia," International Human Rights of Women, 2019, 381-401.

19 Pardan Syafrudin, "Comparative Study on Gono Gini's Assets Due to a Death according to the Islamic Law and Positive Law," Journal of Islamicate Studies 1, no. 1 (2018): 11-29.

${ }^{20}$ Timur Kuran, "Legal roots of authoritarian rule in the Middle East: civic legacies of the Islamic Waqf," The American Journal of Comparative Law 64, no. 2 (2016): 419-54.

${ }^{21}$ Patricia Sloane-White, Corporate Islam: Sharia and the modern workplace (Cambridge University Press, 2017).

${ }^{22}$ Beni Ahmad Saebani, Syamsul Falah, dan Maman Abd Djaliel, "Hukum Perdata Islam di Indonesia," 2011.

${ }^{23}$ Abd Shomad, Hukum islam: Penormaan prinsip syariah dalam bukum indonesia (Kencana, 2017).

24 Afridawati Afridawati, "History, Typology, and Implementation of Islamic Law in Indonesia: Combination of Sharia and Fiqh or the Result of Historical Evolution?," Al-Risalah 21, no. 1 (2021): $33-47$.

${ }^{25}$ Andik Wahyun Muqoyyidin, "Kitab kuning dan tradisi riset pesantren di nusantara," IBD A: Jurnal Kajian Islam Dan Budaya 12, no. 2 (2014): 119-36.
} 
The progress of the common law of Islam in Indonesia cannot be separated from the discussion of Islam as a religion. There is no change from Dutch law to Indonesian law, except for the 1945 Constitution as an Indonesian item compiled on the premise of a crisis. A nation's laws should be more public and neighborly than global and widespread. ${ }^{26}$ The development of common law in Indonesia is divided into pre-independence and postautonomy Islamic common law, the former covering the pioneering timeframe and the latter covering the post-pilgrimage time. There are regularly back and forth positions to decide about the Dutch provincial government and the legal executive depending on Islamic law, going from the type of agency to legal dualism. ${ }^{27}$

In the change period, there are broad freedoms for the Islamic general set of laws to improve the fortunes of the lawful custom in Indonesia, to change measures completely. ${ }^{28}$ One of the confirmations is the order of Law Number 32 of 2004 and the Qanun of the Province of Nangroe Aceh Darussalam regarding the execution of Islamic Shari'ah. There are something like four results of legitimate Islamic ideas created and is relevant in Indonesia. These are fiqh, ulema's fatwas, court choices, and legal guidelines. ${ }^{29}$ Notwithstanding these powerful turns of events, there are numerous Islamic common law issues, clashes, and the advantages and disadvantages of a legitimate occasion. The Indonesian Ulema Council (MUI) gave a fatwa that went against the choice of the Constitutional Court to revoke Article 2 passage (2) of Law Number 1 of 1974 concerning marriage. ${ }^{30}$ The situation with an illconceived kid in the MUI fatwa is compared with that of a two-timing youngster. Kids coming about because of infidelity do not have connection relations, marriage gatekeepers, legacy, and sadaqah with the one who caused her introduction to the world.

Infidelity is a total violation, not a complaint violation, because infidelity is wrongdoing. ${ }^{31}$ The guarantee of offspring from a child that arises because of infidelity to the mother is planned to secure the child's lineage and other related strict arrangements, not as a form of separation. Children with only one parent present are not allowed to be organic

\footnotetext{
${ }^{26}$ Adriaan Bedner, "Indonesian legal scholarship and jurisprudence as an obstacle for transplanting legal institutions," Hague Journal on the Rule of Law 5, no. 2 (2013): 253-73.

${ }^{27}$ Jan Michiel Otto dan J. M. Otto, Sharia and national law in Indonesia (Leiden University Press, 2010).

${ }^{28}$ Euis Nurlaelawati, Modernization, tradition and identity: The Kompilasi Hukum Islam and legal practice in the Indonesian religious courts, vol. 4 (Amsterdam University Press, 2010).

${ }^{29}$ Ahmad Zain Sarnoto dan Lamya Hayatina, "Polarization of the Muslim community towards government policies in overcoming the COVID-19 pandemic in Indonesia," Linguistics and Culture Review 5, no. S1 (2021): 642-52.

${ }^{30}$ Simon Butt, "Between control and appeasement: Religion in five constitutional court decisions," dalam Religion, law and intolerance in Indonesia (Routledge, 2016), 42-67.

${ }^{31}$ Siti Jahroh, "Reaktualisasi Teori Hukuman dalam Hukum Pidana Islam," Jurnal Hukum Islam, 2016.
} 
fathers. In 2005, the Supreme Court concluded that any outsider who wishes to marry an Indonesian woman must save IDR (500,000,000 rupiah) into the balance sheet. Cash is used as collateral to help the couple if their marriage is separated. ${ }^{32}$ In the case of separation, an out" ah must be given, a gift at the time of separation so that the couple can live. Marriage registration is a collection of marriage management information handled by the marriage registrar. In the writing of Islamic law, marriage registration is regulated based on ijtihad. Marriage is one of the bonds that are recommended in Islam. This is done to fulfill God's command so that humans do not fall into disbelief. ${ }^{33}$

\section{Polygamy as civil law in Islam}

Polygamy implies a marriage bond in which one party (the couple) marries more than one wife simultaneously, while monogamy implies a marriage that allows the husband to have one wife for a certain period. ${ }^{34}$ In Islamic law, polygamy is essential for a substantial marriage with a breaking point, only for four women. Polygamy is supported by Muslims depending on Chapter 4 of the Quran. Its part empowers men to marry women "two, three, or four"; However, they must have a single partner if they are "fearful" that they will not have the option of treating them all the same way. ${ }^{35}$ Furthermore, humanity will see a challenge to achieve this despite their most important efforts, as verse 129 shows. Polygamy is taboo in Islam, and the Qur'an recommends monogamy as the primary type of marriage that is adequate in Islam. public arena. ${ }^{36}$

Regarding "being left out or stranded between women," the Qur'an may advocate polygamy if justice can be served by double marriage by the male side. ${ }^{37}$ These conditions include: (1) the wife has no problem with polygamy during or before the marriage contract, and if the spouse refuses, the wife has the privilege of bringing the difference to an Islamic court; (2) the wife does not question polygamy during or before the marriage contract, and if

\footnotetext{
${ }^{32}$ Khaeron Sirin, "Aspek Pemidanaan Dalam Hukum Perkawinan (Analisis Terhadap Perkawinan Yang Tidak Dicatatkan di Indonesia," Al-Risalah 12, no. 01 (2018): 1-15.

33 Maswandi Maswandi, "Pertanggungjawaban Pidana Atas Terbitnya Akta Nikah Karena Poliandri Di Sumatera Utara Dalam Perspektif Hukum Islam (Studi Kasus Putusan Pengadilan Agama Pematang Siantar No. 141/Pdt. G/2011/PA. PSt)" (PhD Thesis, Universitas Islam Negeri Sumatera Utara, 2020).

${ }^{34}$ Desi Fitrianti, "Harta Bersama dalam Perkawinan Poligami Menurut Undang-Undang Nomor 1 Tahun 1974 dan Hukum Islam,” Jurnal Intelektualita: Keislaman, Sosial dan Sains 6, no. 1 (2017): 83-102.

${ }^{35}$ Wibowo, "Studi perbandingan hukum pengaturan kewenangan kejaksaan dalam penuntutan perkara pidana menurut kitab undang-undang hukum acara pidana (KUHAP) dan menurut hukum acara pidana Jepang (Japan Criminal Procedure Code).”

${ }^{36}$ Nani N Jamal, Eni Zulaeha, dan Tintin Supriyatin, "Edukasi Seksual Orang Tua terhadap Anak dan Remaja," Fakultas Ushuluddin UIN SGD Bandung (Fakultas Ushuluddin UIN SGD Bandung, 2019).

${ }^{37}$ Ilhamuddin Ilhamuddin, "Praktik Poligami di Masyarakat Kabupaten Mamuju Sulawesi Barat (Tinjauan Yuridis dan Sosiologis)" (PhD Thesis, Universitas Islam Negeri Alauddin Makassar, 2018).
} 
the husband ignores this, the wife has the option of taking the difference to an Islamic court; (3) wife has two, if one can treat all his women sincerely and fairly, (3) if he is rich enough to handle all their problems. ${ }^{38}$

\section{Evidence in civil in modern Islam context Individual Personal Law}

The law on people (personenrecht) at Burgerlijk Wetboek (BW) is regulated in Book I entitled Van Personen, which contains regulations on legal subjects. ${ }^{39}$ Besides that, it also contains family relations regulations, namely, marriage and rights marital wealth. Sari, ${ }^{40}$ said that everyone, both residents and outsiders, is a holder of rights and commitments who has the privilege to perform lawful acts, including completing agreements with different meetings. Contract law in Indonesia is indeed very volatile because of the whole set of laws that are unique in each of these countries. This article is structured to look at the legal provisions of the meaning of civil law for people who are part of the fundamental civil law as indicated by the Civil Code and Islamic Law. Meliala, ${ }^{41}$ also proven a similar study in a study entitled "Civil Law in the Perspective of BW.".

Sugiswati, ${ }^{42}$ says that marriage is defined as a concept of solidarity between a man and a woman, which results in the creation of property related to marriage. There are two types of property in marriage: personal property and property in marriage. Property acquired during the marriage is called marital property. There are three approaches to examining property in marriage law: Islamic law, general law, and general law. If a marriage ends in divorce, the assets acquired during the marriage are divided. Following Indonesian Islamic Law and Indonesian common law, property in marriage will be divided equally between the spouses; however, according to local law, property in marriage will be divided differently. In contrast to Indonesian Islamic Law and Indonesian Civil Law, property in marriage will be divided differently. ${ }^{43}$

\footnotetext{
${ }^{38}$ M. Miqdam Makfi, "Tinjauan Hukum Islam Terhadap Tradisi Poligami Di Desa Asemjaran Kecamatan Banyuates Kabupaten Sampang Madura,” 2020.

${ }^{39}$ DR Titik Triwulan Tutik dan MH SH, Hukum perdata dalam sistem bukum nasional (Kencana, 2015).

${ }^{40}$ Irda Sari, "Analisis Dampak Pandemi Covid-19 Terhadap Kecemasan Masyarakat: Literature Review," Bina Generasi: Jurnal Kesehatan 12, no. 1 (2020): 69-76.

${ }^{41}$ Meliala, "Hukum Waris Menurut Kitab Undang-Undang Hukum Perdata."

42 Besse Sugiswati, "Konsepsi Harta Bersama Dari Perspektif Hukum Islam, Kitab Undang-Undang Hukum Perdata Dan Hukum Adat," Perspektif 19, no. 3 (2014): 201-11.

${ }^{43}$ Muthmainnah Muthmainnah dan Fattah Setiawan Santoso, "Akibat Hukum Harta Bersama Perkawinan Dalam Pewarisan Di Indonesia Analisis Komparatif Hukum Islam Dan Hukum Adat,” Ulumuddin: Jurnal Ilmuilmu Keislaman 9, no. 1 (2019): 81-96.
} 
Fikri's study, ${ }^{44}$ strengthens our study with the theme of law as God's standard where Islamic law is firm and does not necessarily fall apart by the times, while Islamic law as a law intended for individuals is versatile and accepts all the necessities of life. So, while reacting to changes and progress of local public activity, Islamic law must follow its personal. God's revelation always upholds Islamic law because it is God's law. Again, the quantity of brilliant disclosure is limited, while the quantity of cultural change is unlimited. Thus, the foundation of Islamic law is expected to fill as a link between disclosure and cultural reality, filling the holes in the entire legal chain. Reality must be relentless and open to consistent disclosure, and disclosure should not be isolated from the real world. ${ }^{45}$

Asasriwarnia and Jandra's, ${ }^{46}$ study on comprehensive Islamic law, general law, and customary-based law were essential. Their study uncovers the ideas of correlation of available sets of laws, their sources, history, and examination of the substance of the legal framework. The broad range of legal examinations is characterized by similarities and contrasts to the law's various components. Islamic law thoroughly directs the different parts of human existence in this arrangement, incorporating relationships with the universe, God, and the grand universe. So Islamic law is complete and can provide a sense of security and justice in line with civil law. ${ }^{47}$

In addition to civil law, Indonesia also uses religious law sourced from us sacred and the consensus of the ulama. ${ }^{48}$ The MUI emerged as having a vague disposition towards the popular government. It has recognized several essential rules for a voice-based society and state, such as correspondence under reasonable legal and administrative control. Nonetheless, Dewan is very traditionalist in defending Islamic beliefs and philosophies. ${ }^{49}$ Likewise, Hefner's, ${ }^{50}$ findings on the subject of Islam and majority governance in Indonesia have been pushed to the focal point of strategic considerations and examinations. Examiners differ on whether Indonesia provides a picture of effective popularity-based change in the Muslimmajority country. This article returns to a book compiled almost 20 years earlier, Civil Islam:

\footnotetext{
${ }^{44}$ Fikri Fikri, "Dinamika Hukum Perdata Islam di Indonesia" (TrustMedia Publishing, 2015).

${ }^{45}$ Tutik dan SH, Hukum perdata dalam sistem bukum nasional.

${ }^{46}$ Asasriwarnia Asasriwarnia dan M. Jandra, "Comparison Of Legal System: Islamic Law System, Civil Law, and Common Law," UMRAN-International Journal of Islamic and Civilizational Studies 5, no. 2-1 (2018).

${ }^{47}$ S. H. Sulaikin Lubis, Hukum Acara Perdata Peradilan Agama di Indonesia (Kencana, 2018).

48 Mohamad Abdun Nasir, "The 'Ulamā', fatāwā and challenges to democracy in contemporary Indonesia," Islam and Christian-Muslim Relations 25, no. 4 (2014): 489-505.

${ }^{49}$ Devid Frastiawan Amir Sup, "Cessie Dalam Tinjauan Hukum Islam," Jurisprudensi: Jurnal Ilmu Syariah, Perundangan-Undangan dan Ekonomi Islam 11, no. 1 (2019): 44-73.

${ }^{50}$ Robert W. Hefner, "Whatever happened to civil Islam? Islam and democratisation in Indonesia, 20 years on," Asian Studies Review 43, no. 3 (2019): 375-96.
} 
Muslims and democratization in Indonesia. This resolves the topic of how much the 1998 amendment guarantee has been met.

\section{Civil law regarding family}

Djuniarti, ${ }^{51}$ examines the law of marital property that has taken an essential part in everyday life in every way when marriage is still going as expected. Following the regulation of marriage law, property acquired during the marriage becomes joint property. In formal juridical terms, the definition of joint property is property obtained by a husband and wife during marriage. The end of exploration is that property with individual rights cannot be claimed or combined. Likewise, the Padang, ${ }^{52}$ study about the miracle of mixed marriages between spouses of various identities, considering Indonesian workers and unknown specialists. Problems arise when setting up authentication from a marriage official and planning a different marriage certificate or report. The Indonesian government will provide the correct data and sites to couples who want to get married.

Rizal's study, ${ }^{53}$ the presence of the Ahwal al-Syakhshiyah study program at the Syari'ah Faculty of the State Islamic Institute (IAIN) Kediri is expected to produce legal experts. Understanding this goal should be supported by the dissemination of relevant courses. One of the subjects referred to is polite law, and students are relied on to understand standard law courses better. The creators found very few references in general laws using simple techniques to develop students' understanding further. The issue of civil law related to family law was also carried out by Sudrajat, ${ }^{54}$ who found how the legal protection of children's rights as human rights in the perspective of the family law system in Indonesia.

\section{Heritage in the context of the country}

Moechthar, ${ }^{55}$ studied comprehensive inheritance law instruments in Indonesia, which were isolated into three frameworks; in particular, the general legal instrument for western heirs was obtained from the burgerlijk wetboek, a general legal instrument come from the Al-

${ }^{51}$ Evi Djuniarti, "Hukum Harta Bersama Ditinjau dari Perspektif Undang-Undang Perkawinan dan KUH Perdata," Jurnal Penelitian Hukum De Jure 17, no. 4 (2017): 445-61.

52 STIH Padang, "Perkawinan Antar Negara Di Indonesia Berdasarkan Hukum Perdata Internasional," Jurnal Ilmiah Fakultas Hukum Universitas Udayana 33 (2018): 176.

53 Moch Choirul Rizal, "Restatement Terhadap Konsep Dalam Hukum Tentang Keluarga Sesuai Kewenangan Mengadili Peradilan Agama Di Indonesia,” Repository Publikasi Ilmiah, 2019.

${ }^{54}$ Tedy Sudrajat, "Perlindungan Hukum Terhadap Hak Anak Sebagai Hak Asasi Manusia Dalam Perspektif Sistem Hukum Keluarga Di Indonesia,” Kanun Jurnal Ilmu Hukum 13, no. 2 (2011): 111-32.

${ }^{55}$ Oemar Moechthar, "Kedudukan Negara Sebagai Pengelola Warisan Atas Harta Peninggalan Tak Terurus Menurut Sistem Waris Burgerlijk Wetboek," Yuridika 32, no. 2 (2017): 280-309. 
Qur'an, Al-Hadith, and Ijma Ulama, and the standard of inheritance law. In some instances, the inheritance status of the deceased heir if the deceased heir does not leave the primary heir, and a will, so that the inheritance tradition is classified as a reprehensible inheritance (onbeheerde nalatenschap). The Orphan Court accepted his cooperation to act as the neglected chairman.

Meanwhile, Al-Ghazali, ${ }^{56}$ adopted in common law is a demonstration that balances children with biological children, both in terms of awareness and inheritance. In Islamic law, the reception will not lead to blood relations and does not become the premise and reason for inheritance. This article examines the legal situation of adopted children in inheritance from the books of customary law and Islamic law.

\section{Civil law on property in the context of the state}

Simatupang, ${ }^{57}$ focused on the disharmony of laws and rules in guardianship in Indonesia. Article 366 of the Civil Code communicates that the Heritage Hall is scattered as the trusted overseer in each trust referenced. Regardless, it stops amid a horde of events, especially related to family law and wealth. The review results show that administration ought to, regardless, be finished because the Marriage Law does not yet unequivocally address guardianship. Widanarti, ${ }^{58}$ takes a gander at the legitimate delayed consequences of mixed connections concerning personal assets. Marriage Law 1 of 1974 oversees matters that identify with marriage yet controls the marital property. The complexity of the issue in abundance on account of mixed connections moreover controls worldwide law rules. Like this, the marriage confirmation of appreciation can be finished after the marriage by introducing an application to the court and getting an extreme association.

Yuniarlin and Heriyani, ${ }^{59}$ focused on a review of Islamic law on inheritance halls' ability to supervise non-specialist plenitude. Disappeared individuals do not lose their status as legitimate subjects who have rights and obligations. Along these lines, it is essential for

\footnotetext{
${ }^{56}$ Muhammad Al-Ghazali, "Perlindungan Terhadap Hak-Hak Anak Angkat Dalam Pembagian Harta Waris Perspektif Kitab Undang-Undang Hukum Perdata Dan Hukum Islam," Qiyas: Jurnal Hukum Islam dan Peradilan 1, no. 1 (2016).

57 Taufik H. Simatupang, "Disharmoni Peraturan Perundang-Undangan Di Bidang Pengawasan Perwalian di Indonesia (Lintas Sejarah Dari Hukum Kolonial Ke Hukum Nasional)," Jurnal Penelitian Hukum DE JURE 20, no. 2 (2020): 221-32.

58 Herni Widanarti, “AKIBAT HUKUM PERKAWINAN CAMPURAN TERHADAP HARTA PERKAWINAN (PENETAPAN PENGADILAN NEGERI DENPASAR No: 536/Pdt.P/2015/PN.Dps.)," Diponegoro Private Law Review 2, no. 1 (2018), https://ejournal2.undip.ac.id/index.php/dplr/article/view/2827.

${ }_{59}$ Prihati Yuniarlin dan Endang Heriyani, "TINJAUAN HUKUM ISLAM TERHADAP FUNGSI BALAI HARTA PENINGGALAN DALAM MENGURUS HARTA KEKAYAAN ORANG YANG TIDAK HADIR," Jurnal Media Hukum 25, no. 1 (11 Oktober 2018): 1-9, https://doi.org/10.18196/jmh.2018.0096.1-8.
} 
security interests and property. In Islamic Law, the upheld relationship to oversee missing individuals' resources is a brief zakat association, as shown by the Civil Code; a non-existent resource association is a certifiable awe-inspiring phenomenon. Orlando ${ }^{60}$ shows how the transport of heritage is according to the standard law rules of the Akit faction. The division of inheritance from guards to individuals uses mainly based on law and Islam. The neglected child gets a gift or will be given by his tolerant watchman 33\% of the heritage, and the gift ought to be intentional and certifiable. The examination chooses the execution of heritage to take the children in getting inheritance from the unseasoned guardians and get legal information for the acknowledged adolescents.

\section{CONCLUSION}

This section summarizes the results of a study that aims to understand civil law in the context of contemporary Islam in Indonesia through a review of many publications that discuss civil law in Islam from an Islamic perspective. The core of our findings include that we found civil law in Islamic perspective, marriage law in an Islamic context that emphasizes Islamic views following the state's view, how is the evidence for the study of civil law in an Islamic context; including the prime law of the individual section of the individual, the civil law of the family, the law of inheritance in the Islamic context. We can conclude that Islamic civil law includes Munakahat (everything related to marriage, divorce and its legal consequences); Wiratsat (managing all matters with heirs, heirs, inheritance, and distribution of inheritance); and Mu'amalah (in a unique sense regulating material matters and rights to objects, human relations).

\section{REFERENCES}

Afridawati, Afridawati. "History, Typology, and Implementation of Islamic Law in Indonesia: Combination of Sharia and Fiqh or the Result of Historical Evolution?" Al-Risalah 21, no. 1 (2021): 33-47.

Al-Ghazali, Muhammad. "Perlindungan Terhadap Hak-Hak Anak Angkat Dalam Pembagian Harta Waris Perspektif Kitab Undang-Undang Hukum Perdata Dan Hukum Islam.” Qiyas: Jurnal Hukum Islam dan Peradilan 1, no. 1 (2016).

\footnotetext{
${ }^{60}$ Yohanes Orlando, "Pembagian Waris Menurut Hukum Adat Masyarakat Suku Akit (Studi di Kecamatan Rupat Utara, Pulau Rupat, Kabupaten Bengkalis, Provinsi Riau),” Premise Law Journal 1 (2017): 165006.
} 
Asasriwarnia, Asasriwarnia, dan M. Jandra. "Comparison Of Legal System: Islamic Law System, Civil Law, and Common Law." UMRAN-International Journal of Islamic and Civilizational Studies 5, no. 2-1 (2018).

Aslan. "Pergeseran Nilai Di Masyarakat Perbatasan (Studi tentang Pendidikan dan Perubahan Sosial di Desa Temajuk Kalimantan Barat).” Disertasi dipublikasikan. Pasca Sarjana, 17 Januari 2019. https://idr.uin-antasari.ac.id/10997/.

Bahri, Idik Saeful. Risalah Mahasiswa Hukum. Rasibook, 2017.

Bedner, Adriaan. "Indonesian legal scholarship and jurisprudence as an obstacle for transplanting legal institutions." Hague Journal on the Rule of Law 5, no. 2 (2013): 253-73.

Butt, Simon. "Between control and appeasement: Religion in five constitutional court decisions." Dalam Religion, law and intolerance in Indonesia, 42-67. Routledge, 2016.

Djuniarti, Evi. "Hukum Harta Bersama Ditinjau dari Perspektif Undang-Undang Perkawinan dan KUH Perdata." Jurnal Penelitian Hukum De Jure 17, no. 4 (2017): 445-61.

Erwinsyahbana, Tengku. "Sistem hukum perkawinan pada Negara hukum berdasarkan pancasila." jurnal ilmu bukum 3, no. 1 (2012).

Fikri, Fikri. “Dinamika Hukum Perdata Islam di Indonesia.” TrustMedia Publishing, 2015.

Fitrianti, Desi. "Harta Bersama dalam Perkawinan Poligami Menurut Undang-Undang Nomor 1 Tahun 1974 dan Hukum Islam.” Jurnal Intelektualita: Keislaman, Sosial dan Sains 6, no. 1 (2017): 83-102.

Hajati, Sri, Ellyne Dwi Poespasari, dan Oemar Moechthar. Buku Ajar Pengantar Hukum Indonesia. Airlangga University Press, 2019.

Harto, Bella Aristantia. “Tinjauan Sosiologi Hukum Islam Terhadap Pergeseran Peran dan Fugsi Suami-Isteri dalam Keluarga TKW di Desa Pucanganom Kecamatan Kebonsari Kabupaten Madiun.” PhD Thesis, IAIN Ponorogo, 2021.

Hefner, Robert W. "Whatever happened to civil Islam? Islam and democratisation in Indonesia, 20 years on." Asian Studies Review 43, no. 3 (2019): 375-96.

Ilhamuddin, Ilhamuddin. "Praktik Poligami di Masyarakat Kabupaten Mamuju Sulawesi Barat (Tinjauan Yuridis dan Sosiologis)." PhD Thesis, Universitas Islam Negeri Alauddin Makassar, 2018.

Jahroh, Siti. "Reaktualisasi Teori Hukuman dalam Hukum Pidana Islam.” Jurnal Hukum Islam, 2016.

Jonaedi Efendi, S. H. I., S. H. Johnny Ibrahim, dan MM SE. Metode Penelitian Hukum: Normatif dan Empiris. Prenada Media, 2018. 
Kania, Delila. "Pembelajaran Konsep Hukum Perdata untuk Meningkatkan Kebermaknaan Pendidikan Kewarganegaraan." Jurnal Wawasan Yuridika 31, no. 2 (2016): 154-76.

Kuran, Timur. "Legal roots of authoritarian rule in the Middle East: civic legacies of the Islamic Waqf." The American Journal of Comparative Law 64, no. 2 (2016): 419-54.

Linos, Katerina, dan Melissa Carlson. "Qualitative methods for law review writing." U. Chi. L. Rev. 84 (2017): 213.

Makfi, M. Miqdam. “Tinjauan Hukum Islam Terhadap Tradisi Poligami Di Desa Asemjaran Kecamatan Banyuates Kabupaten Sampang Madura,” 2020.

Maswandi, Maswandi. "Pertanggungjawaban Pidana Atas Terbitnya Akta Nikah Karena Poliandri Di Sumatera Utara Dalam Perspektif Hukum Islam (Studi Kasus Putusan Pengadilan Agama Pematang Siantar No. 141/Pdt. G/2011/PA. PSt).” PhD Thesis, Universitas Islam Negeri Sumatera Utara, 2020.

McKenna, Joseph M., Kathy Martinez-Prather, dan Scott W. Bowman. "The roles of schoolbased law enforcement officers and how these roles are established: A qualitative study." Criminal Justice Policy Review 27, no. 4 (2016): 420-43.

Meliala, Djaja S. "Hukum Waris Menurut Kitab Undang-Undang Hukum Perdata." Nuansa Aulia, 2018.

Moechthar, Oemar. "Kedudukan Negara Sebagai Pengelola Warisan Atas Harta Peninggalan Tak Terurus Menurut Sistem Waris Burgerlijk Wetboek.” Yuridika 32, no. 2 (2017): 280-309.

Muqoyyidin, Andik Wahyun. "Kitab kuning dan tradisi riset pesantren di nusantara." IBDA: Jurnal Kajian Islam Dan Budaya 12, no. 2 (2014): 119-36.

Muthmainnah, Muthmainnah, dan Fattah Setiawan Santoso. "Akibat Hukum Harta Bersama Perkawinan Dalam Pewarisan Di Indonesia Analisis Komparatif Hukum Islam Dan Hukum Adat.” Ulumuddin: Jurnal Ilmu-ilmu Keislaman 9, no. 1 (2019): 81-96.

N Jamal, Nani, Eni Zulaeha, dan Tintin Supriyatin. "Edukasi Seksual Orang Tua terhadap Anak dan Remaja." Fakultas Ushuluddin UIN SGD Bandung. Fakultas Ushuluddin UIN SGD Bandung, 2019.

Nasir, Mohamad Abdun. “The 'Ulamā', fatāwā and challenges to democracy in contemporary Indonesia." Islam and Christian-Muslim Relations 25, no. 4 (2014): 489-505.

Nurlaelawati, Euis. Modernization, tradition and identity: The Kompilasi Hukum Islam and legal practice in the Indonesian religious courts. Vol. 4. Amsterdam University Press, 2010. 
Orlando, Yohanes. "Pembagian Waris Menurut Hukum Adat Masyarakat Suku Akit (Studi di Kecamatan Rupat Utara, Pulau Rupat, Kabupaten Bengkalis, Provinsi Riau).” Premise Law Journal 1 (2017): 165006.

Otto, Jan Michiel, dan J. M. Otto. Sharia and national law in Indonesia. Leiden University Press, 2010 .

Padang, STIH. "Perkawinan Antar Negara Di Indonesia Berdasarkan Hukum Perdata Internasional.” Jurnal Ilmiah Fakultas Hukum Universitas Udayana 33 (2018): 176.

PNH Simanjuntak, S. H. Hukum Perdata Indonesia. Kencana, 2017.

Postema, Gerald J. A Treatise of Legal Philosophy and General Jurisprudence: Volume 11: Legal Philosophy in the Twentieth Century: The Common Law World. Vol. 11. Springer Science \& Business Media, 2011.

Pranadita, Nugraha. Pemodelan Implementasi Hukum: Peranan Manajemen Strategis dalam Implementasi Hukum. Deepublish, 2018.

Rahmatullah, Indra. "Meneguhkan Kembali Indonesia Sebagai Negara Hukum Pancasila." $A D A L A H 4$, no. 2 (2020).

Ramadan, Tariq. Western Muslims and the future of Islam. Oxford University Press, 2003.

Rizal, Moch Choirul. "Restatement Terhadap Konsep Dalam Hukum Tentang Keluarga Sesuai Kewenangan Mengadili Peradilan Agama Di Indonesia.” Repository Publikasi Ilmiah, 2019.

Saebani, Beni Ahmad, Syamsul Falah, dan Maman Abd Djaliel. "Hukum Perdata Islam di Indonesia,” 2011.

Sari, Irda. "Analisis Dampak Pandemi Covid-19 Terhadap Kecemasan Masyarakat: Literature Review." Bina Generasi: Jurnal Kesehatan 12, no. 1 (2020): 69-76.

Sarnoto, Ahmad Zain, dan Lamya Hayatina. "Polarization of the Muslim community towards government policies in overcoming the COVID-19 pandemic in Indonesia.” Linguistics and Culture Review 5, no. S1 (2021): 642-52.

Scalia, Antonin. Common-law courts in a civil-law system: the role of united states federal courts in interpreting the constitution and laws. Princeton University Press, 2018.

Shomad, Abd. Hukum islam: Penormaan prinsip syariah dalam bukum indonesia. Kencana, 2017.

Siagian, Erick Christian Fabrian, Hendra Sulaksana, Mohammad Zaky Kelly Antonio Fernando, Dinda Ayudhia Rachmawati, dan Susilo Sumardi. "SEJARAH SISTEM HUKUM EROPA KONTINENTAL (CIVIL LAW) DAN IMPLEMENTASINYA DI INDONESIA." JURNAL LEX SPECIALIS 2, no. 1 (2021). 
Simatupang, Taufik H. "Disharmoni Peraturan Perundang-Undangan Di Bidang Pengawasan Perwalian di Indonesia (Lintas Sejarah Dari Hukum Kolonial Ke Hukum Nasional).” Jurnal Penelitian Hukum DE JURE 20, no. 2 (2020): 221-32.

Siombo, Marhaeni Ria, dan Henny Wiludjeng. Hukum Adat Dalam Perkembangannya. Penerbit Universitas katolik Indonesia Atma Jaya, 2020.

Sirin, Khaeron. "Aspek Pemidanaan Dalam Hukum Perkawinan (Analisis Terhadap Perkawinan Yang Tidak Dicatatkan di Indonesia.” Al-Risalab 12, no. 01 (2018): 1-15.

Sloane-White, Patricia. Corporate Islam: Sharia and the modern workplace. Cambridge University Press, 2017.

Steiner, Kerstin. "Islam, Law, and Human Rights of Women in Malaysia." International Human Rights of Women, 2019, 381-401.

Sudrajat, Tedy. "Perlindungan Hukum Terhadap Hak Anak Sebagai Hak Asasi Manusia Dalam Perspektif Sistem Hukum Keluarga Di Indonesia.” Kanun Jurnal Ilmu Hukum 13, no. 2 (2011): 111-32.

Sugiswati, Besse. "Konsepsi Harta Bersama Dari Perspektif Hukum Islam, Kitab UndangUndang Hukum Perdata Dan Hukum Adat.” Perspektif 19, no. 3 (2014): 201-11.

Sulaikin Lubis, S. H. Hukum Acara Perdata Peradilan Agama di Indonesia. Kencana, 2018.

Sup, Devid Frastiawan Amir. “Cessie Dalam Tinjauan Hukum Islam.” Jurisprudensi: Jurnal Ilmu Syariah, Perundangan-Undangan dan Ekonomi Islam 11, no. 1 (2019): 44-73.

Syafrudin, Pardan. “Comparative Study on Gono Gini's Assets Due to a Death according to the Islamic Law and Positive Law.” Journal of Islamicate Studies 1, no. 1 (2018): 11-29.

Tutik, DR Titik Triwulan, dan MH SH. Hukum perdata dalam sistem bukum nasional. Kencana, 2015.

Wibowo, Taufiq. "Studi perbandingan hukum pengaturan kewenangan kejaksaan dalam penuntutan perkara pidana menurut kitab undang-undang hukum acara pidana (KUHAP) dan menurut hukum acara pidana Jepang (Japan Criminal Procedure Code)," 2010.

Widanarti, Herni. "AKIBAT HUKUM PERKAWINAN CAMPURAN TERHADAP HARTA PERKAWINAN (PENETAPAN PENGADILAN NEGERI DENPASAR No: 536/Pdt.P/2015/PN.Dps.)." Diponegoro Private Law Review 2, no. 1 (2018). https://ejournal2.undip.ac.id/index.php/dplr/article/view/2827.

Yuniarlin, Prihati, dan Endang Heriyani. “TINJAUAN HUKUM ISLAM TERHADAP FUNGSI BALAI HARTA PENINGGALAN DALAM MENGURUS HARTA 
Understanding Civil Law in The Context of Contemporary Islam in Indonesia

KEKAYAAN ORANG YANG TIDAK HADIR.” Jurnal Media Hukum 25, no. 1 (11 Oktober 2018): 1-9. https://doi.org/10.18196/jmh.2018.0096.1-8. 